\title{
HUBUNGAN ASUPAN SERAT, NATRIUM DAN AKTIVITAS FISIK TERHADAP KEJADIAN OBESITAS DENGAN HIPERTENSI PADA ANAK SEKOLAH DASAR
}

\author{
Dewi Mulad Sari, Binar Panunggal ${ }^{*}$ \\ Program Studi Ilmu Gizi Fakultas Kedokteran Universitas Diponegoro \\ Jl.Dr.Sutomo No.18, Semarang, Telp (024) 8453708, Email : gizifk@ undip.ac.id
}

\begin{abstract}
Background : Obesity related to metabolic syndrome which is one of them was hypertension. Obesity-related hypertension happened not only in adult but also in adolescent and chilhood. Risk factors of obesity-related hypertension among other low dietary fiber intake, high sodium intake and low physical activity.

Objective : The study aimed to determine association of fiber intake, sodium intake, and physical activity to obesityrelated hypertension occurence among elementary school children.

Method : Research design of the study was case control with age and sex matching from 3 different elementary school in Semarang City. Subject were 33 children in case group (obesity related hypertension children) and 33 children in control group (non obesity non hypertension children). Obesity determined by BMI/Age indicator and blood tension using percentil measure. Fiber and sodium intake were calculated by semi-quantitative food frequency questionaire (FFQ), whereas Physical activity measured by physical activity questionaire. The research data were analyzed by chi-square test.

Result : Analysis data result showed that there were no significant association of dietary fiber $(p=0.46)$ and sodium intake $(p=0.28)$ and physical activity $(p=0.33)$ to obesity-related hypertension occurence. Fiber intake $(O R=0.69$; 95\%CI=0.26-1.83) and physical activity $(O R=0.61 ; 95 \% C I=0.23-1.62)$ weren't the risk factor for obesity-related hypertension. Sodium intake $(O R=2.22 ; 95 \% C I=0.51-9.76)$ was a risk factor for obesity-related hypertension occurence, although some study have shown inconclusive result.

Conclusion : There were no significant association of fiber intake, sodium intake, and physical activity to obesityrelated hypertension occurence. High sodium intake increased the risk as much as 2.22 times for obesity-related hypertension occurence among elementary school children.
\end{abstract}

Keywords : fiber; sodium; physical activity; obesity; hypertension; elementary school children

\begin{abstract}
ABSTRAK
Latar belakang : Obesitas berkaitan dengan sindrom metabolik salah satunya hipertensi. Obesitas dengan hipertensi tidak hanya terjadi pada dewasa tetapi juga masa anak dan remaja, salah satunya anak Sekolah Dasar $(S D)$. Faktor yang dapat mempengaruhi kejadian obesitas dengan hipertensi antara lain asupan serat, asupan natrium, dan aktivitas fisik.

Tujuan : Mengetahui hubungan asupan serat, natrium, dan aktivitas fisik terhadap kejadian obesitas dengan hipertensi pada anak SD.

Metode : Desain penelitian case control study dengan matching usia dan jenis kelamin dari 3 SD di kota Semarang. Subjek penelitian terdiri dari 33 kelompok kasus (obesitas dengan hipertensi) dan 33 kelompok kontrol (tidak obesitas tidak hipertensi). Kriteria obesitas menggunakan indikator IMT/U dan tekanan darah menggunakan indikator persentil. Asupan serat dan natrium dihitung dengan food frequency questionaire (FFQ) semi kuantitatif dan aktivitas fisik menggunakan kuesioner aktivitas fisik. Analisa data menggunakan uji Chi Square.

Hasil : Hasil analisis menunjukkan tidak ada hubungan signifikan antara asupan serat $(p=0,46)$, natrium $(p=0,28)$, dan aktivitas fisik $(p=0,33)$ terhadap kejadian obesitas dengan hipertensi. Asupan serat $(O R=0,69 ; 95 \% C I=0,26$ 1,83) dan aktivitas fisik $(O R=0,61 ; 95 \% C I=0,23-1,62)$ bukan merupakan faktor risiko kejadian obesitas dengan hipertensi. Asupan natrium (OR=2,22; 95\%CI=0,51-9,76) merupakan faktor risiko terjadi obesitas dengan hipertensi, tetapi hasil inkonklusif.

Kesimpulan : Asupan serat, natrium, dan aktivitas fisik tidak berhubungan terhadap kejadian obesitas dengan hipertensi. Asupan natrium yang tinggi meningkatkan risiko 2,22 kali kejadian obesitas dengan hipertensi pada anak $S D$.
\end{abstract}

Kata kunci: serat; natrium; aktivitas fisik; obesitas; hipertensi; anak sekolah dasar

\section{PENDAHULUAN}

Obesitas merupakan masalah gizi yang dialami oleh berbagai kelompok masyarakat salah satunya anak Sekolah Dasar (SD). ${ }^{1}$ Penelitian di
Semarang tentang obesitas di SD, menyatakan bahwa persentase obesitas terbesar yaitu SDN Petompon 02 (23,60\%), SD PL Bernadus (23,30 $\%)$, dan SD Hj. Isriati Baiturrahman $01(19,4 \%)^{2}$

${ }^{*}$ Penulis Penanggungjawab 
Apabila anak mengalami obesitas, maka risiko penyakit degeneratif akan meningkat saat dewasa. ${ }^{3}$ Kasus obesitas meningkat dari tahun 2007 sampai 2010. Data Riskesdas tahun 2007 sebanyak 9,50\% anak laki-laki dan 6,40\% anak perempuan usia 614 tahun mengalami obesitas. ${ }^{4}$ Data Riskesdas tahun 2010 menyebutkan bahwa prevalensi obesitas pada anak laki-laki sebanyak $10,70 \%$ dan perempuan $7,70 \% .^{5}$

Obesitas berkaitan dengan sindrom metabolik salah satunya hipertensi. Obesitas dengan hipertensi merupakan penyakit obesitas yang disertai penyakit hipertensi. Penyakit ini diakibatkan oleh kelebihan hormon leptin karena obesitas kronik yang berdampak pada peningkatan reaksi sistem saraf simpatik. Selain itu, dapat juga melalui mekanisme sistem renin-angiotensinaldosteron mengakibatkan retensi cairan dan natrium sehingga menimbulkan penyakit hipertensi. ${ }^{6}$

Obesitas dengan hipertensi menyebabkan peningkatan risiko penyakit jantung. Obesitas dengan hipertensi tidak hanya terjadi pada dewasa tetapi juga selama masa anak dan remaja salah satunya usia 9-12 tahun. ${ }^{3}$ Penelitian di Semarang tahun 2006 pada anak SMP usia 11-16 tahun, menyebutkan bahwa anak obesitas berisiko terkena hipertensi 6,6 kali lebih tinggi dibandingkan dengan overweight. ${ }^{7}$

Asupan serat yang rendah dapat menyebabkan obesitas, karena anak obesitas akan cenderung mengonsumsi makanan tinggi lemak yang lebih mudah cerna dibandingkan serat. ${ }^{8}$ Penelitian di SD $\mathrm{N}$ sompok 01 menyebutkan bahwa anak obesitas yang mengonsumsi serat $<25$ gram (AKG) cenderung mengonsumsi asupan lemak yang tinggi. ${ }^{9}$ Penelitian lain di Amerika tentang asupan serat menyatakan bahwa asupan serat yang rendah $\leq 8,8 \mathrm{~g}$ /hari meningkatkan C-Reactive Protein (CRP) 4 kali lebih tinggi pada orang dengan dua atau tiga risiko penyakit (obesitas, hipertensi, diabetes) dibandingkan dengan orang yang tanpa risiko penyakit. ${ }^{10}$ Asupan serat yang rendah mengakibatkan asam empedu lebih sedikit diekskresi feses, sehingga banyak kolesterol yang direabsorpsi dari hasil sisa empedu. Kolesterol akan semakin banyak beredar dalam darah, menumpuk di pembuluh darah dan menghambat aliran darah sehingga berdampak pada peningkatan tekanan darah. ${ }^{8}$

Asupan natrium juga berkaitan dengan kejadian obesitas dengan hipertensi. Penelitian di Kanada menyebutkan bahwa anak yang mengonsumsi makanan tinggi natrium (> 2200 $\mathrm{mg} / \mathrm{hari}$ ) akan meningkatkan tekanan darah sistolik maupun diastolik. ${ }^{11}$ Penelitian di Australia menyebutkan bahwa peningkatan konsumsi garam $1 \mathrm{~g} / \mathrm{hari}$ dapat meningkatkan konsumsi sugarsweetened beverage sebanyak $17 \mathrm{~g} / \mathrm{hari}$ yang berakibat pada peningkatan risiko obesitas. ${ }^{12}$

Aktivitas fisik mempengaruhi obesitas dengan hipertensi dengan cara mengontrol berat badan dan tekanan darah. ${ }^{13}$ Penelitian di Swiss pada anak pre pubertas dengan obesitas menyebutkan bahwa olahraga aerobik selama 3 bulan dengan frekuensi 3 X60 menit/minggu ditambah 135 menit pelajaran olahraga efektif dalam menurunkan Indeks Massa Tubuh (IMT), tekanan darah sistolik maupun diastolik, dan penanda atherosklerosis yang lain. ${ }^{14}$ Penelitian di Amerika pada anak obesitas dengan aktivitas fisik yang kurang dengan kategori aktivitas ringan menyebutkan bahwa anak yang menonton $\mathrm{TV} \geq 2$ jam memiliki risiko lebih tinggi dibandingkan anak yang menonton $<2$ jam. ${ }^{15}$

Berdasarkan pentingnya masalah obesitas dengan hipertensi dan belum banyak penelitian tentang obesitas dengan hipertensi pada anak SD maka, peneliti ingin mengetahui hubungan asupan serat, natrium, dan aktivitas fisik terhadap risiko kejadian obesitas dengan hipertensi pada anak SD.

\section{METODE}

Jenis penelitian ini menggunakan desain case control study dengan matching usia dan jenis kelamin. Subjek penelitian adalah anak SD usia 912 tahun. Pengambilan subjek penelitian dengan metode consecutive sampling. Penelitian ini dilaksanakan di 3 SD kota Semarang yaitu SD Petompon 02, SD PL Bernadus, dan SD Hj. Isriati Baiturrahman 01. ${ }^{2}$ Pelaksanaan penelitian pada bulan April-Juni 2013. Jumlah subjek penelitian sebanyak 70 anak terdiri dari 35 kelompok kasus (obesitas dengan hipertensi) dan 35 kelompok kontrol (tidak obesitas tidak hipertensi).

Kriteria Inklusi penelitian in yaitu anak SD umur 9-12 tahun, mampu menjawab pertanyaan melalui wawancara, subyek dan orang tua tidak mempunyai riwayat penyakit hipertensi, tidak minum obat dan bersedia menjadi subjek penelitian dengan mengisi informed consent, kelompok kasus Z-skor IMT/U > $2 \mathrm{SD}$, tekanan darah $\geq 95$ persentil menurut umur, tinggi badan, dan jenis kelamin, sedangkan kelompok kontrol Z-skor IMT/U -2 sampai dengan 1 SD, tekanan darah sistolik dan atau diastolik 50 sampai 90 persentil menurut umur, tinggi badan, dan jenis kelamin. Kriteria eksklusi penelitian ini yaitu 
mengundurkan diri menjadi subjek penelitian dan pindah sekolah.

Variabel dependent dalam penelitian ini adalah kejadian obesitas dengan hipertensi pada anak SD dan variabel independent adalah asupan serat, natrium, dan aktivitas fisik. Obesitas dihitung dengan Z-skor IMT/U. Kategori obesitas IMT/U > 2SD dan normal yaitu IMT/U -2 sampai dengan 1 SD. ${ }^{16}$ Pengolahan dan analisa data IMT/U menggunakan software WHO Anthroplus.

Tekanan darah satuannya adalah $\mathrm{mmHg}$ dan pengkategorian menggunakan indikator persentil menurut NHBPEP (National High Blood Pressure Education Program). Kategori hipertensi apabila tekanan darah sistolik dan atau diastolik $\geq 95$ persentil dan kategori normal (tidak obesitas tidak hipertensi) jika tekanan darah sistolik dan atau diastolik 50 sampai 90 persentil menurut umur, tinggi badan, dan jenis kelamin. Cara pengukuran tekanan darah diawali dengan mengistirahatkan subyek selama 5 menit kemudian memeriksa tekanan darah menggunakan sphygmomanometer air raksa dan stetoskop pada lengan kiri. Pengukuran diulang $\geq 3$ kali dengan waktu tunggu 2 menit setelah pengukuran sebelumnya. ${ }^{17}$

Data asupan serat dan natrium diperoleh melalui kuesioner dengan wawancara FFQ (Food
Frequency Questionaire) semi kuantitatif. Kategori asupan serat rendah yaitu $\leq 8,8$ gram/hari dan tinggi $>8,8$ gram/hari. ${ }^{10}$ Kategori asupan natrium rendah yaitu $\leq 2200 \mathrm{mg} /$ hari dan tinggi $>2200$ $\mathrm{mg} /$ hari. ${ }^{11}$ Pengolahan dan analisa data asupan serat dan natrium menggunakan software Nutrisurvey.

Aktivitas fisik yaitu durasi melakukan kegiatan sehari-hari selama 7 hari dihitung berdasarkan menit, melalui wawancara dengan pengisian kuesioner modifikasi Physical Activity Questionaire Children (PAQ-C). ${ }^{18}$ Kategori aktivitas fisik rendah apabila melakukan kegiatan < 45 menit/hari dengan jenis aktivitas fisik sedang sampai dengan berat dan tinggi jika melakukan kegiatan $\geq 45$ menit/hari dengan jenis aktivitas fisik sedang sampai dengan berat. ${ }^{14}$

Pengumpulan data diawali dengan skrining di 3 SD dengan persentase obesitas terbesar yaitu SD N Petompon 02, SD PL Bernadus, dan SD Hj. Isriati Baiturrahman $01 .^{2}$ Pengambilan subjek penelitian dengan consecutive sampling dari semua anggota populasi sampai jumlah subjek terpenuhi. Data yang dikumpulkan yaitu identitas subjek, IMT, tekanan darah, data asupan serat dan natrium, serta aktivitas fisik. Analisis nilai besar risiko (Odds Ratio) menggunakan uji Chi Square.

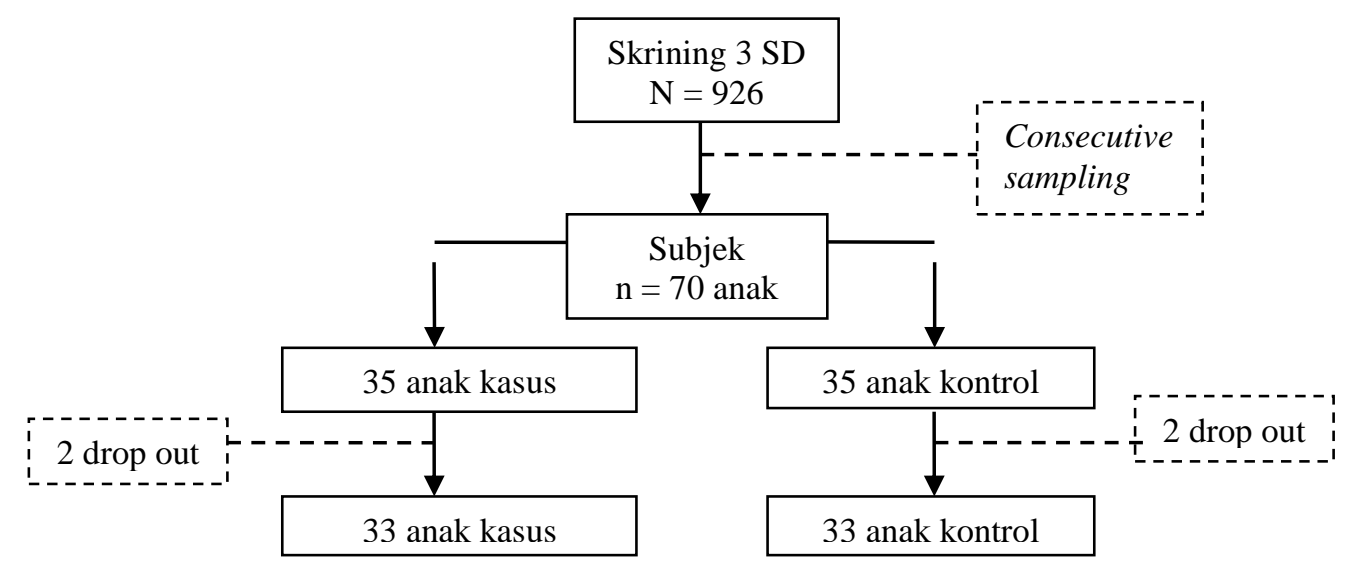

Bagan 1. Alur kerja penelitian

HASIL PENELITIAN Karakteristik subjek penelitian
Subjek penelitian sebanyak 70 anak dari 3 SD kota Semarang. Subjek sampai akhir penelitian sebanyak 66 anak.

Tabel 1. Karakteristik subjek penelitian

\begin{tabular}{lcccc}
\hline \multirow{2}{*}{ Variabel } & \multicolumn{2}{c}{ Kasus } & \multicolumn{3}{c}{ Kontrol } \\
\cline { 2 - 5 } & $\mathrm{n}$ & $\%$ & $\mathrm{n}$ & $\%$ \\
\hline Jenis Kelamin & & & & \\
Laki-laki & 22 & 66,67 & 22 & 66,67 \\
Perempuan & 11 & 33,33 & 11 & 33,33
\end{tabular}


Usia

9 tahun

10 tahun

2

6,06

45,45

2

6,06

11 tahun

39,39

45,45

12 tahun

13

9,09

13

39,39

3

3

9,09

Tabel 2. Distribusi Z-skor dan tekanan darah

\begin{tabular}{lcccccc}
\hline \multirow{2}{*}{ Variabel } & \multicolumn{3}{c}{ Kasus } & \multicolumn{3}{c}{ Kontrol } \\
\cline { 2 - 7 } & mean \pm SD & Min & Maks & mean \pm SD & Min & Maks \\
\hline Z-skor IMT/U (SD) & $2,84 \pm 0,65$ & 2,04 & 4,57 & $-0,22 \pm 0,98$ & $-1,98$ & 1,00 \\
\hline Tekanan darah & & & & & & \\
Sistolik (mmHg) & $128 \pm 3,54$ & 125 & 130 & 100 & 100 & 100 \\
$\quad 9$ tahun & $120 \pm 9,58$ & 100 & 130 & $99 \pm 7,04$ & 90 & 110 \\
10 tahun & $129 \pm 6,40$ & 120 & 140 & $99 \pm 8,62$ & 80 & 110 \\
11 tahun & $137 \pm 5,77$ & 130 & 140 & $106 \pm 5,77$ & 100 & 110 \\
12 tahun & & & & & & \\
Diastolik (mmHg) & 80 & 80 & 80 & 70 & 70 & 70 \\
9 tahun & $83 \pm 5,94$ & 70 & 90 & $65 \pm 6,40$ & 60 & 80 \\
10 tahun & $84 \pm 11,21$ & 70 & 110 & $62 \pm 4,38$ & 60 & 70 \\
11 tahun & $93 \pm 5,77$ & 90 & 100 & $63 \pm 5,77$ & 60 & 70 \\
12 tahun & & & & & & \\
\hline
\end{tabular}

Tabel 3. Deskripsi asupan serat, natrium, dan aktivitas fisik berdasarkan kelompok kasus dan kontrol

\begin{tabular}{lcccccc}
\hline \multirow{2}{*}{\multicolumn{1}{c}{ Variabel }} & \multicolumn{2}{c}{ Kasus } & \multicolumn{3}{c}{ Kontrol } \\
\cline { 2 - 7 } & Median & Min & Maks & Median & Min & Maks \\
\hline Asupan serat (g) & 8,1 & 1,40 & 28,10 & 9,8 & 4,80 & 35,90 \\
Asupan natrium (mg) & 1210,80 & 105,50 & 3765,20 & 936,00 & 155,20 & 3240,30 \\
Aktivitas fisik (menit) & 30,00 & 1,43 & 178,57 & 47,86 & 11,43 & 218,57 \\
\hline
\end{tabular}

Sebagian besar subjek penelitian berusia 10 tahun dengan jenis kelamin laki-laki. Rerata Z-skor IMT/U kelompok kasus 2,84 $\pm 0,65$ SD. Rerata tekanan darah kelompok kasus dan kontrol berbeda sesuai dengan kelompok umur.

Median asupan serat berdasarkan kelompok kasus dan kontrol masing-masing yaitu 8,1 gram/hari dan 9,8 gram/hari. Median asupan natrium sebanyak $1210,80 \mathrm{mg} /$ hari pada kelompok kasus dan $936 \mathrm{mg} / \mathrm{hari}$ pada kelompok kontrol.
Sementara itu, aktivitas fisik kelompok kasus memiliki median sebesar 30 menit/hari sedangkan kelompok kontrol sebesar 47,86 menit/hari.

Hubungan asupan serat, natrium, dan aktivitas fisik terhadap kejadian obesitas dengan hipertensi

Data hubungan asupan serat, natrium, dan aktivitas fisik terhadap kejadian obesitas dengan hipertensi disajikan pada Tabel 5.

Tabel 5. Hubungan Asupan Serat, Natrium, dan Aktivitas Fisik Terhadap Kejadian Obesitas dengan Hipertensi

\begin{tabular}{|c|c|c|c|c|c|c|c|}
\hline \multirow{2}{*}{ Faktor Risiko } & \multicolumn{2}{|c|}{ Kasus } & \multicolumn{2}{|c|}{ Kontrol } & \multirow[b]{2}{*}{$\mathrm{p}$} & \multirow{2}{*}{ OR } & \multirow{2}{*}{$95 \% \mathrm{CI}$} \\
\hline & $\mathrm{n}$ & $\%$ & $\mathrm{n}$ & $\%$ & & & \\
\hline \multicolumn{8}{|l|}{ Asupan serat } \\
\hline $\begin{array}{l}\text { Rendah } \\
\text { gram })\end{array} \quad(\leq \quad 8,8$ & 17 & 51,51 & 14 & 42,42 & \multirow[t]{2}{*}{0,46} & \multirow[t]{2}{*}{0,69} & \multirow[t]{2}{*}{$0,26-1,83$} \\
\hline Tinggi (> 8,8 gram) & 16 & 48,48 & 19 & 57,58 & & & \\
\hline \multicolumn{8}{|l|}{ Asupan natrium } \\
\hline Tinggi (> $2200 \mathrm{mg}$ ) & 6 & 18,18 & 3 & 9,09 & \multirow[t]{2}{*}{0,28} & \multirow[t]{2}{*}{2,22} & \multirow[t]{2}{*}{$0,51-9,76$} \\
\hline Rendah $(\leq 2200$ & 27 & 81,82 & 30 & 90,91 & & & \\
\hline
\end{tabular}


mg)

\begin{tabular}{|c|c|c|c|c|c|c|c|}
\hline \multicolumn{8}{|l|}{ Aktivitas fisik } \\
\hline $\begin{array}{l}\text { Rendah } \\
\text { menit })\end{array}$ & 19 & 57,57 & 15 & 45,45 & 0,33 & 0,61 & $0,23-1,62$ \\
\hline Tinggi ( $>45$ menit) & 14 & 42,42 & 18 & 54,55 & & & \\
\hline
\end{tabular}

Berdasarkan Tabel 4 diketahui bahwa asupan serat $(\mathrm{p}=0,46)$, asupan natrium $(\mathrm{p}=0,28)$, dan aktivitas fisik $(\mathrm{p}=0,33)$ tidak berhubungan terhadap kejadian obesitas dengan hipertensi. Asupan serat $(\mathrm{OR}=0,69 ; 95 \% \mathrm{CI}=0,26-1,83)$, dan aktivitas fisik $(\mathrm{OR}=0,61 ; 95 \% \mathrm{CI}=0,23-1,62)$ bukan merupakan faktor risiko terhadap kejadian obesitas dengan hipertensi. Asupan natrium $(\mathrm{OR}=2,22$; $95 \% \mathrm{CI}=0,51-9,76)$, hal ini berarti asupan natrium meningkatkan risiko 2,22 kali untuk terjadi obesitas dengan hipertensi pada anak SD. Namun, interval kepercayaan asupan natrium melewati 1 yang berarti bahwa hasil inkonklusif.

\section{PEMBAHASAN}

Obesitas dengan hipertensi merupakan salah satu penyakit komorbiditas obesitas saat anak usia 9-12 tahun. Apabila saat anak mengalami obesitas dengan hipertensi maka risiko obesitas meningkat saat dewasa dan berkembang menjadi penyakit jantung. ${ }^{3}$ Faktor risiko kejadian obesitas dengan hipertensi dapat disebabkan oleh rendahnya asupan serat dan aktivitas fisik serta asupan natrium yang tinggi.

Penelitian ini memberikan hasil bahwa asupan serat tidak berhubungan dengan kejadian obesitas dengan hipertensi. Hasil sama ditunjukkan dengan penelitian di Semarang yang menyebutkan asupan serat tidak berhubungan dengan obesitas. ${ }^{9}$ Penelitian di Spanyol memberikan hasil yang berbeda menyebutkan bahwa asupan serat berhubungan dengan obesitas. Hal ini disebabkan oleh jumlah subjek penelitian ini lebih sedikit $(n=66)$ dibandingkan penelitian di Spanyol $(n=369)$ dengan desain rancangan yang sama menggunakan case control study. ${ }^{19}$

Asupan serat yang cukup dapat mencegah kejadian obesitas dengan hipertensi. Serat mengabsobsi air, memperluas penyerapan di usus, dan memperlambat pergerakan makanan pada saluran pencernaan sehingga menimbulkan rasa kenyang lebih lama. ${ }^{8}$ Selain itu, beberapa jenis serat seperti pektin, gum, glukan, dan lignin yang membentuk chitosan mengikat asam lemak dan kolesterol sehingga tidak dapat membentuk misel. Misel dibutuhkan untuk hasil akhir pencernaan lemak, apabila misel tidak terbentuk maka mengakibatkan penurunan jumlah lemak dalam tubuh. $^{20}$

Asupan serat yang rendah mengakibatkan asam empedu lebih sedikit diekskresi feses, sehingga banyak kolesterol yang di absorpsi dari hasil sisa empedu. Semakin banyak kolesterol beredar dalam darah, maka akan semakin besar penumpukan lemak di pembuluh darah dan menghambat aliran darah yang berdampak pada peningkatan tekanan darah. ${ }^{8}$

Asupan natrium pada penelitian ini tidak berhubungan terhadap kejadian obesitas dengan hipertensi. Hasil tersebut berbeda dengan hasil penelitian di Australia yang menyebutkan bahwa asupan natrium berhubungan dengan konsumsi sugar-sweetened beverage (SSB). Anak yang mengonsumsi SSB > 1 sajian memiliki hubungan dengan peningkatan risiko obesitas. ${ }^{12}$ Penelitian yang tidak berhubungan disebabkan oleh penggunaan FFQ semi kuantitatif untuk mengetahui asupan natrium. FFQ semi kuantitatif digunakan untuk mengetahui kebiasaan makan seseorang dan risiko suatu penyakit, tetapi memiliki kelemahan bias data under atau overestimated. ${ }^{21}$ Penelitian oleh Feng J.He menyebutkan bahwa asupan natrium lebih akurat dihitung dengan output urin dibandingkan FFQ semi kuantitatif karena dapat menggambarkan asupan natrium dalam jaringan. ${ }^{22}$

Asupan natrium pada kelompok kasus lebih tinggi dibandingkan kelompok kontrol. Asupan tinggi natrium menyebabkan hipertropi sel adiposit akibat proses lipogenik pada jaringan lemak putih, jika berlangsung terus menerus akan menyebabkan penyempitan saluran pembuluh darah oleh lemak dan berakibat pada peningkatan tekanan darah. ${ }^{23}$ Selain hal tersebut, individu dengan berat badan berlebih dan obesitas kemungkinan besar memiliki sensitifitas garam yang berpengaruh pada tekanan darah. Sensitifitas garam adalah kondisi seseorang mudah mengalami peningkatan tekanan darah dengan mengonsumsi makanan tinggi natrium (bentuk garam) dan cara untuk menurunkan tekanan darah dengan mengurangi asupan garam. ${ }^{8}$

Asupan natrium yang tinggi meningkatkan risiko 2,22 kali kejadian obesitas dengan hipertensi. Namun, karena 95\%CI=0,51-9,76 (melewati angka 1) menyebabkan hasil 
inkonklusif. Penyebab hasil inkonklusif kemungkinan disebabkan karena tidak mengikutsertakan faktor lain yang mempengaruhi kejadian obesitas dengan hipertensi dalam analisa. Selain itu penyebab jauhnya interval kepercayaan yaitu terdapat jajanan kemasan pabrik yang tidak mencantumkan nilai natrium dalam informasi gizi dan kesulitan dalam menganalisa nilai natrium pada MSG.

Penelitian ini memberikan hasil bahwa aktivitas fisik tidak berhubungan secara signifikan terhadap kejadian obesitas dengan hipertensi. Hal ini berbeda dengan penelitian sebelumnya di Amerika pada anak obesitas dengan aktivitas fisik yang kurang salah satunya menonton TV yang termasuk dalam kategori aktivitas ringan menyebutkan bahwa menonton TV 2-4 jam dan > 4 jam masing-masing memiliki risiko hipertensi 2,5 dan 3,3 kali lebih besar dibandingkan dengan anak yang menonton TV $<2$ jam. ${ }^{15}$ Perbedaan ini disebabkan oleh perbedaan kategori aktivitas fisik.

Aktivitas fisik memiliki sifat protektif terhadap kejadian obesitas dengan hipertensi. Aktivitas fisik secara teratur termasuk olahraga aerobik dan latihan kekuatan otot tiga kali/minggu minimal 60 menit ditambah pelajaran olahraga 135 menit/minggu selama 3 bulan mampu menurunkan tekanan darah, BMI Z-skor, lemak total, lemak abdominal, meningkatkan fat-free mass, dan kemampuan kardiorespirasi pada anak obesitas pre pubertas. ${ }^{14}$ Olahraga berfungsi untuk mengontrol berat badan pada obesitas dan menstabilkan heart rate pada hipertensi atau sindrom metabolik lain karena menggunakan lemak sebagai energi. ${ }^{13}$

\section{KETERBATASAN PENELITIAN}

Penelitian ini tidak menghitung nilai natrium pada jajanan kemasan pabrik (tidak mencantumkan informasi gizi) dan nilai natrium pada MSG. Faktor lain yang mungkin berpengaruh terhadap kejadian obesitas dengan hipertensi (misal : pendidikan atau sosial ekonomi orang tua) tidak diikutsertakan dalam penelitian ini.

\section{SIMPULAN}

a. Tidak terdapat hubungan asupan serat terhadap risiko kejadian obesitas dengan hipertensi pada anak SD.

b. Tidak terdapat hubungan asupan natrium terhadap risiko kejadian obesitas dengan hipertensi pada anak SD.

c. Tidak terdapat hubungan aktivitas fisik terhadap risiko kejadian obesitas dengan hipertensi pada anak SD. d. Asupan natrium yang tinggi meningkatkan risiko 2,22 kali kejadian obesitas dengan hipertensi, akan tetapi hasil inkonklusif karena tidak mengikutsertakan faktor lain yang mungkin lebih berpengaruh terhadap kejadian obesitas dengan hipertensi dalam analisa.

\section{SARAN}

Bagi sekolah, dapat memberikan himbauan kepada siswa-siswi untuk memantau berat badan dan tekanan darah setiap bulan untuk pencegahan kejadian obesitas dengan hipertensi.

Bagi subjek, disarankan untuk meningkatkan informasi gizi terutama natrium dan serat dalam makanan kemasan [batasan natrium normal (Na): $1500 \mathrm{mg} /$ hari] serta meningkatkan konsumsi air.

Saran untuk penelitian selanjutnya agar meneliti berbagai macam faktor risiko (misal: pendidikan atau sosial ekonomi orang tua) terhadap kejadian obesitas dengan hipertensi pada anak sekolah dasar dengan jumlah subyek penelitian yang lebih banyak dan desain rancangan lain.

\section{UCAPAN TERIMA KASIH}

Peneliti mengucapkan terima kasih kepada subjek penelitian atas partisipasi, waktu dan kerjasamanya selama kegiatan penelitian. Terima kasih kepada pembimbing dan reviewer atas masukan dan saran yang telah diberikan. Terima kasih kepada orang tua dan teman-teman angkatan 2009-2011 yang telah membantu pengambilan data penelitian ini.

\section{DAFTAR PUSTAKA}

1. Sjarif DR. Buku Ajar Nutrisi Pediatrik dan Penyakit Metabolik jilid 1. Jakarta: Penerbit IDAI; 2011.p.230.

2. Mexitalia M., Susanto JC, Faizah Zinatul, Hardian. Hubungan Pola Makan dan Aktivitas Fisik pada Anak dengan Obesitas Usia 6-7 Tahun di Semarang. Media Medika Indonesia 2005;40:2.

3. Gahagan Sheila. Overweight and Obesity In: Kliegman RM, Stanton BF, Schor NF, St. Geme III JW, Behrman RE. Nelson Textbook of Pediatrics 19th ed. Philadelphia: WB Saunders; 2011.p.179.

4. KEMENKES. RISKESDAS 2007. Departemen Kesehatan: Badan Penelitian dan Pengembangan Kesehatan. 2008.p.45.

5. KEMENKES. RISKESDAS 2010. [serial online] 2010 Des [cited 2012 Jul 16];3:44p. Available from: URL: HYPERLINK http://www.litbang.depkes.go.id/sites/downloa 
d/buku_laporan/lapnas_riskesdas2010/Laporan riskesdas_2010.pdf

6. Hall JE, da-Silva AA, Brandon Elizabeth, Stec DE, Ying Zhekang, Jones DW. Pathophysiology of Obesity-Induced Hypertension and Target Organ Damage in: Comprehensive Hypertension. New York: Elsevier; 2007.p.447-68.

7. Mexitalia M., Herumuryawan M, Sakundarno M., Subagio HW, Soemantri Agustinus. Hipertensi pada Obesitas Masa Anak. Media Medika Indonesia 2010;44:1:1-6.

8. Thompson JL, Manore MM, Voughan LA. Science of Nutrition. $2^{\text {nd }}$ ed. USA: Pearson Education Inc.; 2011.p.126-7, 345.

9. Kharismawati Ririn, Sunarto. Hubungan tingkat Asupan Energi, Protein, Lemak, Karbohidrat, dan Serat dengan Status Obesitas Pada Siswa SD (skripsi). Semarang : Universitas Diponegoro. 2010.

10. King DE, Mainous AG, Egan BM, Woolson RF, Geesey ME. Fiber and C-Reactive Protein in Diabetes, Hypertension, and Obesity. Diabetes Care 2005;28:6.

11. Institute of Medicine. Dietary Reference Intakes for Water, Potassium, Sodium, Chloride and Sulfate. Washington, DC: National Academy Press; 2004.p.386.

12. Grimes CA, Riddell LJ, Campbell KJ, Nowson CA. Dietary Salt Intake, Sugar-Sweetened Beverage Consumption, and Obesity Risk. Pediatrics 2013;131:14.

13. Hartono Andry. Terapi Gizi dan Rumah Sakit ed.2. Jakarta: EGC 2006.p.160.

14. Lambert NJF, Aggoun Yacine, Marchand LM, Martin XE, Herrmann FR, Beghetti Maurice. Physical Activity Reduces Systemic Blood Pressure and Improves Early Markers of Atherosclerosis in Pre-Pubertal Obese Children. Journal of the American College of Cardiology 2009; 54:25.

15. Pardee PE, Norman GJ, Lustig RH, Preud'homme Daniel, Schwimmer JB. Television Viewing and Hypertension in Obese Children. Am J Prev Med 2007;33(6):439-43.

16. KEMENKES. Keputusan Menteri Kesehatan Indonesia Nomor: 1995/MENKES/SK/XII/2012 tentang Standar Antropometri Penilaian Status Gizi Anak. KEMENKES RI Direktorat Jenderal Bina Gizi dan Kesehatan Ibu dan Anak, Direktorat Bina Gizi 2011.p.4.

17. National High Blood Pressure Education Program Working Group on High Blood Pressure in Children and Adolescents. The Fourth Report on the Diagnosis, Evaluation, and Treatment of High Blood Pressure in Children and Adolescents. Pediatrics 2004;114:555.
18. Kowalski KC, Crocker PRE, Donen RM. The Physical Activity Questionnaire for Older Children (PAQ-C) and Adolescent (PAQ-A) Manual. [serial online] 2004 [cited 2013 March 24];5-7p. Available from: URL: HYPERLINK http://www.dapatoolkit.mrc.ac.uk/document/en/PAQ/PAQ_man ual.pdf

19. Puchau Blanca, Ochoa Mc, Zulet Ma, Marti Amelia, Martínez Ja, Members Genoi. Dietary Total Antioxidant Capacity and Obesity in Children and Adolescents. [serial online] 2010 [cited 2013 Aug 01];1-20p. Available from: URL:

HYPERLINK. http://dspace.unav.es/dspace/bitstream/10171/1 9242/2/Manuscript IJFSN2.pdf.

20. Gropper SS, Smith JL, Groff JL. Advanced Nutrition and Human Metabolism $5^{\text {th }}$ ed. USA: Wadsworth Cengange Learning; 2009.p.115.

21. Gibson RS. Principle of Nutritional Assesment 2nd ed. New York: Oxford university Press; 2005.p.49, 158.

22. He FJ, MacGregor GA. Importance of Salt in Determining Blood Pressure in Children : Meta-Analysis of Controlled Trials. Hypertension. 2006;48:861-69.

23. Fonseca-Alaniz MH, Brito LC, Borges-Silva CN, Takada Julie, Andreotti Sandra, Lima FB. High Dietary Sodium Intake Increases White Adipose Tissue Mass and Plasma Leptin in Rats. Obesity 2007;5:9. 